\title{
Announcement of the resignation of Herbert Zimmerman as an Associate Editor
}

\section{Geoffrey Burnstock ${ }^{1}$}

Published online: 22 March 2019

(C) Springer Nature B.V. 2019

Herbert Zimmerman has retired as an Associate Editor of our journal. He has been a tower of strength in supporting and developing our journal over the years and has been much appreciated by the purinergic community. We wish him much joy in his retirement.

I am pleased to announce that Samuel J. Fountain has agreed to take his place as an Associate Editor and I am confident that he will be a success.

\section{Compliance with ethical standards}

Conflict of interest Geoffrey Burnstock declares that he has no conflict of interest.

Ethical approval This article does not contain any studies with human participants or animals performed by any of the authors.

Publisher's note Springer Nature remains neutral with regard to jurisdictional claims in published maps and institutional affiliations.
Geoffrey Burnstock

gburnstock@unimelb.edu.au

1 Department of Pharmacology and Therapeutics, The University of Melbourne, Parkville, VIC 3010, Australia 